\title{
Forum
}

\section{Correcting the Record on Leo Strauss}

When I was young we thought we could count on the New York Times for accuracy. But we've received nothing near accuracy in the Times's recent articles about Leo Strauss and his influence. The real question about those articles should be, it seems to me, What has happened to the Times? That's beyond my competence. It might not be a very appropriate topic for a daily newspaper, but since the Times has spread the stuff it has about a man who deserves much better, people who know something about Strauss and Straussians should be allowed to try to straighten out their misinformed readers. Looking for demons is not the best way to account for election results one doesn't like.

Brent Staples's prejudiced outburst, to paraphrase one of Strauss's favorite authors, Jane Austen, does not deserve the compliment of rational opposition. Richard Bernstein tried and succeeded at being more fair. But first some facts. Robert Bork is not a Straussian. (I think he'd be better off, if he were.) In fact, he has been criticized in print (not as a judge, but as a thinker, or scholar) for his relativism by more than one Straussian. Both William Bennett and William Kristol have studied and taught philosophy. They both exhibit the kind of good sense that indicates they might have been influenced by Leo Strauss. While it is true that most of Strauss's students are labeled politically as more or less conservative, there are some thoughtful Straussians who are clearly known as liberals, and who, for instance, supported Bill Clinton for president. There is no single contemporary political stance that follows necessarily from Strauss's teaching.

The one person who, understandably, has ticked off the Times's writers most is my old friend and fellow student, Allan Bloom. "Professor Strauss appealed to conservatives like $\mathrm{Mr}$. Bloom because he was unapologetically elitist"' (Bernstein). Elitism, used in this way, sounds almost like some congenital disease. People who use the word seem to think that it automatically licenses them to ignore the political arguments of those they disagree with. The closest natural, nonideological word to what the users of the term call elitist is probably the word snob. Leo Strauss was in many ways extraordinary, but his manners reflected his rural small town background: they were simple, direct, and natural, in no way snobbish. Allan Bloom too was certainly no snob, but occasionally he allowed himself to look like one.

What attracted us to Strauss was no mystery. We had been attracted to philosophy and especially Plato by our undergraduate studies. Strauss's courses and person were unlike anything we had seen before (or have seen since). Books we thought we had understood fairly well turned out to be far more challenging, fascinating, bold, careful, and intricate than anyone had ever led us to believe. In his teaching Strauss himself exhibited a delight and joy in learning that could not help but be catching. The first effect of all this was quite humbling: we learned that what we thought was our best was not good enough. I can still hear the "sinister" elitist Bloom, in the middle of a discussion after one of those classes saying something like, "Oh Larry, isn't it wonderful that two little guys like us can take part in these things!' Allan Bloom was a thoughtful, sometimes brilliant, very articulate, pesky, sometimes outrageous, man. He was also a lot of fun, which explains in part why he was such an effective teacher.

When we were in college, the dominant view in the social sciences was Max Weber's that statements of fact and judgments of value must be strictly distinguished, that social science must be ethically neutral. What first attracted many of us was Strauss's powerful critique, if not refutation, of that view: it became possible for us to argue, as social scientists, that segregation in the south (and north) was wrong, that Joseph McCarthy was a dangerous demagogue, that liberal democracy was better than Marxist totalitarianism: it freed us from the debilitating view that to attempt to understand what constitutes a good society is nothing more than spelling out one's own emotional preferences.

Critics confuse Strauss's critique of the philosophy of liberalism with an attack on liberal democracy itself, despite the fact that he criticizes the philosophy in part for its failure to defend liberal democratic institutions adequately. There is an entire book dedicated to this subject: The Crisis of Liberal Democracy: a Straussian Perspective, K. L. Deutsch and W. Soffer, eds., [SUNY Press, 1987]. The best article I know on this topic is in that book, "Leo Strauss and the Crisis of Liberal Democracy," by Hilail Gildin. It includes the observation, "That Strauss and the classics favored the rule of law rather than men and were averse to arbitrary government is not plain to all. That is because although their support of the rule of law was unhesitating, their approval of it was not unqualified."

The most intelligent and adequate defense of the rule of law must not blind itself to its inescapable defects. Gildin carefully explains why Strauss could argue "that liberal or constitutional democracy comes closer to what the classics demanded than any alternative that is viable in our age." Most, if not all of us, run up against what we believe to be petty and not so petty injustices almost every day. It's not too difficult to appreciate why decent people dream about 
or long for perfectly wise and just governors, for what Plato referred to as "philosopher kings." Strauss taught, following Plato, why, despite the purity and nobility of that longing, it was not, and could perhaps never be, politically viable; that, given human beings as we know them, the second best, the rule of law, is the politically best. All this should remind politically literate Americans of The Federalist, No. 51.

Some final remarks about the buzz word elitism. Those who use the word, it seems to me, misunderstand the virtues of American democracy: the good in their minds which is opposed to the evil, elitism, would seem to be unbridled egalitarian democracy. The word elite is, of course, originally

French, derived from the word for elect. It is a collective noun meaning basically the elect, those who have been elected or chosen, sometimes by God or nature, for some special task. The founder of the Democratic Party used a classical Greek word for elite: "May we not even say, that that form of government is the best, which provides the most effectually for a pure selection of these natural aristoi into the offices of government? The artificial aristocracy is a mischievous ingredient in government . . ." (Thomas Jefferson, Letter to John Adams, 10/28/1813). The founder of the Republican Party cautions us: "I think the authors of [the Declaration of Independence] intended to include all men, but they did not intend to declare all men equal in all respects. They did not mean to say all were equal in color, size, intellect, moral developments, or social capacity. They defined with tolerable distinctness, in what respects they did consider all men created equal-equal in "certain inalienable rights, among which are life, liberty, and the pursuit of happiness." (Abraham Lincoln, Springfield, Illinois, 6/26/1857).

American democracy, I believe most people would agree, stands or falls by free elections. Free elections would seem to presuppose both inequalities of ability to fulfill the offices for which the elections are held, and the capacities of vot- ers roughly to discern those inequalities. The "nice" word for these inequalities is merit. Free elections, to sum up, introduce a principle of merit into our political system, predicated on inequalities of ability to fulfill the offices for which the elections are held. Representative democracy, The Federalist teaches, is the way to avoid the usual pitfalls of direct democracy: The specter of direct electronic democracy, the threats to genuinely deliberate and rational democracy, should cause us to reconsider those arguments carefully.

The health and long life of liberal democracy, both the classics and The Federalist teach, depend upon an enlightened citizenry that is clear about the limitations as well as the virtues of democracy. No one, as far as I know, put it better than Lincoln (in his First Inaugural): "A majority held in restraint by constitutional checks and limitations, and always changing easily with deliberate changes of popular opinion and sentiment is the only true sovereign of a free people." Unbridled egalitarian democracy is one of the most direct roads through demagoguery to despotism. Bridled, or constitutional and representative, democracy would seem to be the way for those who are interested in combining political freedom with high civilization over the long haul.

Laurence Berns

St. John's College

\section{Politics and Literature: Still Alive and Well}

As an "outsider" as far as the practicalities of American academia are concerned, I have been privileged to play some part in the recognition of the importance of "politics and literature" in the discipline as recognized by "the emergence of an Organized Section devoted to the study of politics and literature," reported in the Symposium on Literature and Politics in the June 1995 issue of $P S$. Catherine Zuckert concludes her brief introduction with the comment that the contributions to this symposium, originally delivered at a roundtable at the 1994 Annual Meeting, "What Literature Can Teach Us About Politics," "provide . . examples of some of the kinds of work that can be done in this new subfield."

The appearance of this work, as a major feature in $P S$, is so welcome that $\mathrm{I}$ hesitate to quibble, particularly with Catherine Zuckert herself, whose work in this subfield I have been aware of and have acknowledged, both personally and publicly, over the last 15 years or so. But there, in effect, is the basis of a necessary, rather than merely pedantic, reservation. The Organized Section is indeed new: the subfield certainly is not.

For instance, on the semi-organized level, as my 1983 PS survey of the "politics and literature" scene indicates, APSA has an honorable record of encouragement dating from at least the early 1960s. And as I also indicated there, and in my updating in 1993, many American political scientists have long taught, published and delivered conference papers on "politics and literature." ("Politics and Literature," News for Teachers of Political Science, Fall 1983, pp. 17-19 [American Political Science Association]; " Only Connect: Politics and Literature 10 Years Later, 1982-92," PS: Political Science \& Politics, June 1993, pp. 257-62).

Mention should also be made, in this context, of Benjamin Barber and Michael McGrath's edited collection, The Artist and Political Vision (Brunswick, NJ: Transaction Books, 1981) and of the papers that I edited in Reading Political Stories: Representations of Politics in Novels and Pictures (Savage, MD: Rowman \& Littlefield, 1992), both of which well demonstrate what Zuckert refers to in relation to the symposium contributions: that they "represent different approaches and interests," "are intended to be suggestive," and "provide elegant and enticing examples of some of the kinds of work that can be done." Indeed, the roundtable papers printed in $P S$ nicely complement the earlier indications of what can be done.

The same issue of $P S$ that contains the symposium also includes the provisional program for the 
1995 Annual Meeting. Those of us who have sometimes despaired about the lack of imagination-and recourse to imaginative sources-of our colleagues should be encouraged by the number of paperssome dozen or so outside of the
Organized Section panels-that refer to art forms of various kinds. I welcome the evidence that film and drama, as well as fiction and poetry, are being brought into political analysis and discussion in ways that, as Catherine Zuckert and I, and many others, from a variety of political science perspectives, have long argued, can only enhance political understanding.

Maureen Whitebrook

University of Sheffield

\section{Moving?...... Moving?...... Moving?...... Don't Forget to Notify APSA}

To ensure that all your subscriptions, membership information, and mailings reach you, return this form to APSA at least one month before you move.

Name:

\section{Work Address:}

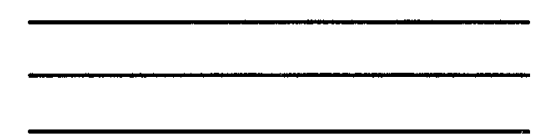

Phone/Fax:
Membership Number:

$$
\text { Home Address: }
$$

E-Mail:

APSA will mail to your work address unless indicated otherwise. Please mark with an $H$ which items to send to the home address: Renewals Journals PSN

Please return to:

Membership Office, American Political Science Association 1527 New Hampshire Ave., NW, Washington, DC 20036;

\section{or fax : (202) 483-2657}

